DOI: $10.15193 /$ zntj/2019/119/292

\author{
MAREK ANGOWSKI, TOMASZ KIJEK, ADAM SKRZYPEK
}

\title{
WPLYW JAKOŚCIOWYCH DETERMINANT PRODUKTÓW MLECZARSKICH NA WYBÓR DYSKONTÓW JAKO MIEJSCA ICH ZAKUPU PRZEZ MŁODYCH NABYWCÓW
}

\begin{abstract}
Streszczenie
Przemiany zachodzące w sektorze handlowym powodują, że współczesny rynek produktów żywnościowych charakteryzuje się dużą zmiennością i nieprzewidywalnością. Znajomość i zrozumienie czynników kształtujących wybór produktów i miejsc ich zakupu przez nabywców jest ważnym elementem kreowania strategii konkurencyjnej podmiotów działających na danym rynku W Polsce obserwowany jest rozwój sieci dyskontowych. Do niedawna polskich nabywców zachęcały do sklepów dyskontowych przede wszystkim niskie ceny, jednak z czasem rosnące wymagania klientów tych sklepów stały się głównym czynnikiem rozwoju nowych modeli sprzedaży w dyskontach. Rozpoczęły one proces zmian koncepcji swoich formatów poprzez ulepszenie oferty towarów pod względem jakości.

Celem pracy była ocena wpływu wybranych cech jakościowych produktów żywnościowych na decyzje nabywców związane z wyborem sklepów dyskontowych jako miejsca zakupu. Część badawczą opracowano na podstawie badań sondażowych, które zostały przeprowadzone w 2016 roku na grupie 358 młodych nabywców produktów mleczarskich, przy wykorzystaniu metody doboru celowego. W zbieraniu danych wykorzystano metodę CAWI wspomaganą metodą PAPI. W analizach statystycznych opisujących zachowania badanych nabywców zastosowano analizę czynnikową, a do modelowania decyzji konsumentów w zakresie wyboru miejsca zakupu (tj. sklepu dyskontowego) wykorzystano model probitowy. W przeprowadzonych badaniach potwierdzono kluczowe znaczenie cech jakościowych przy podejmowaniu decyzji zakupowych młodych nabywców produktów mleczarskich. Po przeanalizowaniu wpływu czynników jakościowych na wybór sklepu dyskontowego jako miejsca zakupu produktów mleczarskich stwierdzono, że najsilniejszy wpływ na decyzje młodych konsumentów miały cechy sensoryczne oraz zdrowotność produktów.
\end{abstract}

Słowa kluczowe: sklepy dyskontowe, produkty mleczarskie, zachowania młodych nabywców, jakość

Dr M. Angowski, dr hab. T. Kijek, prof. nadzw., Wydz. Ekonomiczny, Uniwersytet Marii Curie Skłodowskiej w Lublinie, Pl. M. Curie-Skłodowskiej 5, 20-031 Lublin, dr A. Skrzypek, Wydz. Nauk Ekonomicznych i Prawnych, Uniwersytet Przyrodniczo-Humanistyczny w Siedlcach, ul. Żytnia 39, 08-110 Siedlce. Kontakt:tomasz.kijek@poczta.umcs.lublin.pl 


\section{Wprowadzenie}

Proces podejmowania decyzji nabywczych na rynku żywności jest złożony. Jego przebieg zmienia się wraz z sytuacją społeczno-ekonomiczną, przemianami kulturowymi oraz rozwojem cywilizacyjnym. Zmieniające się potrzeby i preferencje konsumentów, zmiany stylu życia, zwiększanie się zakresu, rodzaju i dostępności informacji o produktach czy też przemiany zachodzące w sektorze handlowym sprawiają, że współczesny rynek produktów żywnościowych charakteryzuje się dużą zmiennością i nieprzewidywalnością [21, 24]. Znajomość i zrozumienie czynników wpływających na wybór produktów i miejsc ich zakupu przez nabywców staje się ważnym elementem kształtowania strategii konkurencyjnej podmiotów działających na danym rynku [5].

Obecnie można zaobserwować zmiany zachodzące w strukturze handlu detalicznego w Polsce, które są spowodowane rosnącą konkurencją wynikającą ze zmiany uwarunkowań rynkowych $\mathrm{w}$ zakresie postępującej globalizacji, przemian gospodarczych i społeczno-kulturowych oraz rozwoju technologii informacyjnych i komunikacyjnych (ICT). W związku z tym przedsiębiorstwa, które chcą osiągać i utrzymywać trwałą przewagę konkurencyjną muszą przyjąć strategię „orientacji na nabywcę” polegającą na dostarczaniu konsumentowi produktów w odpowiedniej ilości i jakości, po korzystnej cenie oraz w dogodnym miejscu i czasie [1].

Jednym z głównych kierunków zmian w strategiach handlowych jest modernizowanie dotychczasowych kanałów dystrybucji i uruchamianie nowych oraz wykorzystywanie nowych technik sprzedażowych. Głównym motywem ich wprowadzania jest potrzeba ciągłego dostosowywania się do wymagań konsumentów oraz chęć osiągnięcia trwałej przewagi konkurencyjnej. Podstawą skutecznej strategii staje się budowanie i utrzymywanie odpowiednich relacji sprzedażowych ze swoimi nabywcami. Przedsiębiorstwa mogą to osiągnąc poprzez systematyczne badanie i analizowanie zachowań nabywców na rynku oraz opracowanie na podstawie pozyskanych informacji odpowiedniej oferty towarowej. W przypadku produktów żywnościowych bardzo istotne jest uwzględnianie w przygotowywanych strategiach aspektów jakości i bezpieczeństwa żywności. [6, 14].

Sieci sklepów dyskontowych to alternatywna forma sprzedaży detalicznej w stosunku do tradycyjnych jej form realizowanych przez super- i hipermarkety [1]. Do głównych przewag konkurencyjnych sklepów dyskontowych można zaliczyć kluczową rolę niskiej ceny w strategii ich pozycjonowana na rynku oraz minimalizowanie kosztów prowadzenia działalności [11]. Sklepy dyskontowe w swoich strategiach marketingowych odwołują się do racjonalności wyborów i pragmatyzmu nabywców, a podstawę oferty stanowią produkty zaspokajające podstawowe potrzeby [11].

Do głównych cech wyróżniających dyskonty na tle innych formatów handlowych można zaliczyć $[11,12,22,23]$ : konkurencyjne, zwykle najniższe w regionie ceny w stosunku do innych formatów sprzedażowych, ograniczony asortyment, duże zna- 
czenie marek własnych, bardzo dobra lokalizacja, duże parkingi, proste wyposażenie i wystrój sklepu, oszczędności w kosztach logistycznych, minimalne zatrudnienie oraz bardzo agresywna promocja w zakresie reklamy oraz aktywizacji sprzedaży.

W ostatnich latach obserwowana jest wyraźna dominacja sieci dyskontowych na rynku produktów żywnościowych. Według raportu firmy Nielsen [15] z 2018 roku sklepy dyskontowe miały 32,4-procentowy udział w sprzedaży żywności w Polsce, czyli blisko dwa razy tyle, ile średnie sklepy spożywcze (16,5 \%) czy supermarkety $(15,2 \%)$. Ze względu na dużą wrażliwość cenową polskich nabywców do sklepów dyskontowych przekonywały przede wszystkim konkurencyjne ceny. Z czasem jednak rosnące wymagania klientów stały się głównym czynnikiem rozwoju nowego modelu sprzedaży wśród sieci dyskontowych. Dyskonty rozpoczęły proces zmiany w koncepcji swoich formatów poprzez podwyższanie jakości oferowanych towarów. Pomimo wizerunku niskocenowego sprzedawcy, sklepy dyskontowe zaczynają przyciągać klientów także jakością produktów, wyjątkowymi ofertami oraz bardzo intensywną komunikacją marketingową [13].

Jedną z ważniejszych pozycji w strukturze asortymentowej sklepów dyskontowych są produkty żywnościowe. Wzrost zamożności nabywców oraz zwiększanie się ich świadomości żywieniowej wpłynęły znacząco na postrzeganie przez nich produktów żywnościowych w aspekcie cechy jakościowych.

W literaturze przedmiotu postrzeganie i ocena jakości w procesie nabywania produktów żywnościowych przedstawiane są jako pojęcie bardzo złożone [7]. Barska [3] wskazuje, że ,w zależności od rodzaju produktu spożywczego i typu nabywcy na jakość mogą składać się wskaźniki sensoryczne, funkcjonalne i ekonomiczne, odżywcze i zdrowotne oraz preferencje konsumenckie”. Według Szczuckiego [19] ,jakość artykułów żywnościowych to stopień zdrowotności, atrakcyjności sensorycznej i dyspozycyjności w szerokim konsumenckim i społecznym zakresie, istotny tylko w granicach możliwości wyznaczonych przewidzianymi dla tych produktów surowcami, technologią i ceną". Kafel [10] z kolei definiuje jakość ,jako wynik oczekiwań związanych z zakupem i użytkowaniem produktu, a główne cechy pożądanej jakości żywności to: bezpieczeństwo dla konsumenta, właściwe cechy sensoryczne, odpowiednie wartości odżywcze, wysoka funkcjonalność i użyteczność oraz wartość rynkowa odpowiadająca relacji między ceną a kosztem produkcji”.

Problematyka jakości ma kluczowe znaczenie w projektowaniu strategii marketingowej produktów żywnościowych, ponieważ są to produkty związane z zaspokojeniem podstawowych potrzeb fizjologicznych człowieka oraz wpływają na jego poziom zdrowia i życia. W związku z tym konsument będzie poszukiwał takich produktów, które umożliwią mu jak najlepsze zaspokojenie jego oczekiwań i potrzeb $[4,16]$. 
Celem pracy była ocena wpływu wybranych czynników jakościowych produktów mleczarskich na decyzje młodych nabywców związane z wyborem sklepów dyskontowych jako miejsca zakupu.

\section{Material i metody badań}

Na podstawie przeprowadzonych studiów literaturowych sformułowano następujące pytania badawcze:

- Czy są różnice w postrzeganiu cech produktów jako determinant wyboru sklepu dyskontowego w przekroju wybranych grup młodych nabywców (płeć, miejsce zamieszkania, dochód)?

- Jakie cechy jakościowe produktu wpływają na wybór sklepu dyskontowego?

Część doświadczalną opracowano na podstawie badań sondażowych, które zostały przeprowadzone w 2016 roku na grupie 358 młodych nabywców (studentów) żywności przy wykorzystaniu metody doboru celowego. Jako główne kryteria doboru do badanej próby przyjęto wiek respondentów (18 - 25 lat) oraz dokonywanie zakupów produktów mleczarskich w ciągu ostatniego roku. Głównym sposobem zbierania danych była internetowa metoda CAWI (Computer Assisted Web Interview) - wywiad przeprowadzany za pomocą elektronicznej wersji kwestionariusza umieszczonego w serwisie Surveymonkey, wspomagana metodą PAPI (Paper and Pen Personal Interview) - bezpośredni wywiad przeprowadzany przez ankietera z wykorzystaniem papierowej wersji kwestionariusza. Kwestionariusz składał się z pytań dotyczących oceny zachowań i postaw młodych nabywców na rynku produktów mleczarskich. Oceny determinant wyboru produktów mleczarskich mierzone były za pomocą pięciostopniowej skali porządkowej, na której 1 oznaczało czynnik nieistotny, 2 - raczej nieistotny, 3 - nie mam zdania, 4 - raczej istotny, a 5 - czynnik istotny. Zdecydowaną większość respondentów stanowiły kobiety (70,9\%), osoby zamieszkujące wieś $(58,1 \%)$, o dochodach na członka gospodarstwa domowego kształtujących się poniżej $1000 \mathrm{zł}$ $(53,1 \%)$.

W celu redukcji liczby zmiennych opisujących zachowania nabywców zastosowano analizę czynnikową. $\mathrm{W}$ tradycyjnym modelu analizy czynnikowej duża liczba wewnętrznie powiązanych zmiennych pierwotnych zastępowana jest mniejszą liczbą czynników (zmiennych), które są silnie skorelowane ze wszystkimi zmiennymi wyjściowymi lub ich grupami. Model analizy czynnikowej miał postać [2]:

$$
X_{j}=\sum_{l=1}^{w} a_{j l} F_{l}+a_{j} U_{j} j=1, \ldots, p
$$

gdzie: $X_{j}$ - zmienna rzeczywista (wyjściowa), która podlega obserwacji $F_{l}-$ czynnik wspólny, $U_{j}$ - czynnik swoisty obejmujący też efekt działania elementów losowych, 
$a_{j l}$ - ładunki czynnikowe określające siłę wpływu 1-tego czynnika na j-tą zmienną pierwotną oraz $a_{j}$ - ładunek czynnika specyficznego.

Do modelowania decyzji konsumentów w zakresie wyboru miejsca zakupu (tj. sklepu dyskontowego) wykorzystano model probitowy o postaci [8]:

$$
\begin{aligned}
y_{i}^{*} & =x_{i}^{\prime} \beta+\varepsilon_{i}, \quad \varepsilon_{i} \sim N[0,1] \\
y_{i} & =\left\{\begin{array}{lll}
0, & \text { jeżeli } & y_{i}^{*} \leq 0 \\
1, & \text { jeżeli } & y_{i}^{*}>0
\end{array}\right.
\end{aligned}
$$

gdzie: $y_{i}^{*}$ - zmienna latentna, $y_{i}-$ zmienna (losowa) obserwowana o rozkładzie Bernoulliego z prawdopodobieństwami:

$\operatorname{Prob}\left[y_{i}=1 \mid x_{i}\right]=\Phi\left(x_{i}^{\prime} \beta\right) \operatorname{Prob}\left[y_{i}=0 \mid x_{i}\right]=1-\Phi\left(x_{i}^{\prime} \beta\right), x_{i}^{\prime}-$ wektor zmiennych egzogenicznych, $\beta$ - wektor parametrów oraz $\varepsilon_{i}$ - składnik losowy o rozkładzie normalnym.

\section{Wyniki badań i dyskusja}

Zgodnie z przyjętą koncepcją badania do charakterystyk jakościowych produktów mleczarskich zaliczono: wygląd, smak, zapach, termin przydatności do spożycia, certyfikat jakości oraz zdrowotność. W tab. 1. przedstawiono uśrednione oceny znaczenia poszczególnych czynników/zmiennych przy podejmowaniu decyzji zakupu produktów mleczarskich. Dodatkowo dokonano porównania średnich ocen w grupach wyodrębnionych na podstawie kryteriów różnicujących, takich jak: płeć, dochód netto przypadający na członka gospodarstwa domowego i aktualne miejsce zamieszkania.

Najbardziej istotnymi czynnikami przy podejmowaniu decyzji zakupowych były smak i zapach produktów mleczarskich. Uzyskane wyniki są zgodne z rezultatami Nieżurawskiego i wsp. [17], z których wynika, że konsumenci oceniając jakość kupowanych produktów mleczarskich biorą pod uwagę przede wszystkim ich skład oraz cechy sensoryczne [17]. Kolejnym czynnikiem mającym istony wpływa na wybór produktów mleczarskich był termin przydatności do spożycia. Czynnik ten jest związany z elastycznością i wygodą konsumpcji żywności, ale przede wszystkim $z$ bezpieczeństwem jej spożywania. Kluczowe znaczenie tego atrybutu dla konsumentów produktów mleczarskich akcentują również Haas i wsp. [9]. Cechami produktów o mniejszym znaczeniu dla badanych nabywców okazały się zdrowotność i certyfikaty jakości. Biorąc pod uwagę kryteria rożnicujące postawy konsumentów wobec jakości, można stwierdzić, że kobiety przywiązują większą wagę do poszczególnych cech jakości w trakcie procesu wyboru produktu. Jak wskazuje Szwacka [20], może to być efektem doświadczenia i większej wiedzy kobiet na temat produktów żywnościowych, gdyż to właśnie kobiety relatywnie częściej robią zakupy żywności. 
Tabela 1. Znaczenie cech jakości produktów mleczarskich przy podejmowaniu decyzji zakupowych

Table 1. Importance of quality attributes of dairy products while making purchasing decisions

\begin{tabular}{|c|c|c|c|c|c|c|c|}
\hline \multirow{3}{*}{$\begin{array}{c}\text { Cecha } \\
\text { Attribute }\end{array}$} & \multicolumn{7}{|c|}{ Ocena / Evaluation } \\
\hline & \multirow{2}{*}{$\begin{array}{l}\text { Próba } \\
\text { Total }\end{array}$} & \multicolumn{2}{|c|}{ Płeć / Sex } & \multicolumn{2}{|c|}{$\begin{array}{l}\text { Dochód netto } \\
\text { Net income }\end{array}$} & \multicolumn{2}{|c|}{$\begin{array}{c}\text { Miejsce } \\
\text { zamieszkania } \\
\text { Place of residence }\end{array}$} \\
\hline & & $\begin{array}{l}\text { Mężczyzna } \\
\text { Man }\end{array}$ & $\begin{array}{l}\text { Kobieta } \\
\text { Woman }\end{array}$ & $\begin{array}{l}<1000 \\
\text { PLN }\end{array}$ & $\begin{array}{c}>1000 \\
\text { PLN }\end{array}$ & $\begin{array}{c}\text { Wieś } \\
\text { Village }\end{array}$ & $\begin{array}{l}\text { Miasto } \\
\text { City }\end{array}$ \\
\hline Wygląd Appearance & 4,34 & $4,22 *$ & $4,38 *$ & 4,36 & 4,30 & 4,38 & 4,27 \\
\hline Smak / Taste & 4,65 & $4,56 * *$ & $4,69 * *$ & 4,65 & 4,66 & 4,65 & 4,65 \\
\hline Zapach / Smell & 4,61 & $4,49 * *$ & $4,67 * *$ & 4,64 & 4,58 & 4,63 & 4,60 \\
\hline $\begin{array}{c}\text { Termin przydatności } \\
\text { do spożycia } \\
\text { Expiration date }\end{array}$ & 4,55 & $4,38 * *$ & $4,61 * *$ & $4,66^{* *}$ & 4,42 & $4,62 * *$ & $4,45^{* *}$ \\
\hline $\begin{array}{l}\text { Certyfikat jakości } \\
\text { Quality certificate }\end{array}$ & 3,68 & 3,63 & 3,70 & $3,76^{*}$ & $3,58 *$ & 3,71 & 3,63 \\
\hline $\begin{array}{l}\text { Zdrowotność } \\
\text { Healthfulness }\end{array}$ & 3,97 & 3,92 & 3,99 & 4,04 & 3,90 & 4,03 & 3,89 \\
\hline
\end{tabular}

Objaśnienia / Explanatory notes:

** - różnica statystycznie istotna przy $\mathrm{p}<0,05$ / statistically significant difference at $\mathrm{p}<0.05$; * różnica startystycznie istotna przy $\mathrm{p}<0,1$ / statistically significant difference at $\mathrm{p}<0.1 ; \mathrm{n}=358$.

Źródło / Source: opracowanie własne / the authors' own study

W celu zbadania zależności pomiędzy analizowanymi wymiarami jakości żywności posłużono się współczynnikiem korelacji rang Spearmana. W tab. 2. zestawiono wartości współczynników korelacji dla poszczególnych par zmiennych. Stwierdzono, że najsilniej skorelowane są cechy opisujące atrakcyjność sensoryczną produktów mleczarskich. Istnienie takich zależności jest zrozumiałe, gdyż odczucie ogólnej jakości gotowego produktu jest efektem oddziaływania podstawowych cech jakości, tj. wyglądu, smaku (smakowitości) i zapachu oraz interakcji zachodzących między nimi. Zidentyfikowane relacje są potwierdzeniem wyników badań innych autorów. Przykładowo, Sajdakowska i wsp. [18] wykazali, że cechy jakości hedonicznej, w tym artybuty sensoryczne produktów mleczarskich, są ze sobą silnie powiązane i pozwalają na wyodrębnienie czynnika ukrytego powiązanego z tymi cechami.

Przy uwzględnieniu współzależności pomiędzy sensorycznymi cechami jakości wyodrębniono, za pomocą analizy czynnikowej, jeden czynnik ukryty, przenoszący inforamcje o postawach młodych nabywców wobec smaku, wyglądu oraz zapachu produktów mleczarskich. Wartości nowego czynnika (atrybuty sensoryczne) wraz z pozostałymi cechami jakości zostały wykorzystane w modelu probitowym do opisu skłonności konsumentów do dokonywania zakupów w sklepach dyskontowych. Wyniki oszacowań parametrów modelu przedstawiono w tab. 3. 
Tabela 2. Współczynniki korelacji między cechami jakości produktów mleczarskich

Table 2. Correlation coefficients between attributes of quality of dairy products

\begin{tabular}{||c|c|c|c|c|c|c||}
\hline $\begin{array}{c}\text { Cecha } \\
\text { Attribute }\end{array}$ & $\begin{array}{c}\text { Wygląd } \\
\text { Appearance }\end{array}$ & $\begin{array}{c}\text { Smak } \\
\text { Taste }\end{array}$ & $\begin{array}{c}\text { Zapach } \\
\text { Smell }\end{array}$ & $\begin{array}{c}\text { Termin } \\
\text { przydatności do } \\
\text { spożycia } \\
\text { Expiration date }\end{array}$ & $\begin{array}{c}\text { Certyfikat } \\
\text { jakości } \\
\text { Quality } \\
\text { certificate }\end{array}$ & $\begin{array}{c}\text { Zdrowotność } \\
\text { Healthfulness }\end{array}$ \\
\hline $\begin{array}{c}\text { Wygląd } \\
\text { Appearance }\end{array}$ & 1 & - & - & - & - & - \\
\hline Smak/ Taste & $0,54^{*}$ & 1 & - & - & - & - \\
\hline Zapach / Smell & $0,54^{*}$ & $0,74^{*}$ & 1 & - & - & - \\
\hline $\begin{array}{c}\text { Termin } \\
\text { przydatności do } \\
\text { spożycia } \\
\text { Expiration date }\end{array}$ & $0,26^{*}$ & $0,44^{*}$ & $0,42^{*}$ & 1 & - & - \\
\hline $\begin{array}{c}\text { Certyfikat } \\
\text { jakości } \\
\text { Quality } \\
\text { certificate }\end{array}$ & $0,24^{*}$ & $0,28^{*}$ & $0,31^{*}$ & $0,36^{*}$ & 1 & 1 \\
\hline $\begin{array}{c}\text { Zdrowotność } \\
\text { Healthiness }\end{array}$ & $0,30^{*}$ & $0,32^{*}$ & $0,30^{*}$ & $0,32^{*}$ & $0,47 *$ & \\
\hline \hline
\end{tabular}

Objaśnienia / Explanatory notes:

* - współczynnik korelacji statystycznie istotny przy $\mathrm{p}<0,05$ / statistically significant correlation coefficient at $\mathrm{p}<0.05 ; \mathrm{n}=358$.

Źródło / Source: opracowanie własne / the authors' own study

Tabela 3. Wyniki oszacowania parametrów modelu opisującego wpływ cech jakości produktów mleczarskich na wybór sklepu dyskontowego jako miejsca zakupu $(\mathrm{n}=358)$

Table 3. Estimates of model parameters describing impact of quality attributes of dairy products on selecting discount store as place of purchase $(n=358)$

\begin{tabular}{|c|c|c|c|}
\hline Zmienna / Variable & $\begin{array}{c}\text { Współczynnik } \\
\text { Coefficient }\end{array}$ & $\begin{array}{c}\text { Błąd standardowy } \\
\text { Standard error }\end{array}$ & $\mathrm{p}<|\mathrm{z}|$ \\
\hline $\begin{array}{c}\text { Atrybuty sensoryczne } \\
\text { Sensory attributes }\end{array}$ & 0,25 & 0,12 & 0,04 \\
\hline $\begin{array}{c}\text { Termin przydatności do spożycia } \\
\text { Expiration date }\end{array}$ & 0,00 & 0,11 & 0,99 \\
\hline $\begin{array}{c}\text { Certyfikat jakości } \\
\text { Quality certificate }\end{array}$ & $-0,084$ & 0,08 & 0,30 \\
\hline Zdrowotność / Healthfulness & 0,16 & 0,08 & 0,06 \\
\hline Stała / Constant & $-1,17$ & 0,54 & 0,03 \\
\hline LR $\chi^{2}(4)=10,49$ Prob $>\chi^{2}=0,03$ & \multicolumn{3}{|l}{} \\
\hline
\end{tabular}

Źródło / Source: opracowanie własne / the authors' own study 
Na podstawie uzyskanych wyników wykazano pozytywny wpływ atrybutów sensorycznych oraz zdrowotności produktów mleczarskich na skłonność młodych konsumentów do zakupu w sklepach dyskontowanych. Wpływ pozostałych zmiennych okazał się nieistotny. Zidentyfikowane zależności można tłumaczyć strategiczną reorientacją sklepów dyskontowych w Polsce, które w coraz większym stopniu dostosowują się do wymagań jakościowych klientów. W przypadku żywności, w tym produktów mleczarskich, wymagania te dotyczą przede wszystkim cech sensorycznych oraz zdrowotności. Klienci dokonując zakupów w dyskontach, oczywiście będą poszukiwać atrakcyjnej ceny, ponieważ taki jest format tych sklepów, ale cena przestaje być jedynym kryterium wyboru produktu. Warto podkreślić, że coraz większe znaczenie cech jakościowych w procesie wyboru produktów to nie tylko efekt lepszej sytuacji ekonomicznej polskich gospodarstw, ale też wynik zmian związanych ze wzrostem świadomości konsumenckiej młodych nabywców.

Przedstawione badania mają charakteru pilotażowy, jednak wnioski mogą stanowić podstawę do przeprowadzenia kolejnych, bardziej pogłębionych badań i analiz w celu poszukiwania efektywniejszych strategii pozyskiwania nabywców przez sklepy dyskontowe na rynku produktów mleczarskich.

\section{Wnioski}

1. W badaniach potwierdzono kluczowe znaczenie cech sensorycznych w decyzjach zakupowych młodych nabywców produktów mleczarskich.

2. Największe różnice w postrzeganiu roli jakości w decyzjach zakupowych wśród badanych respondentów wystąpiły w grupach wyodrębnionych ze względu na kryterium płci.

3. Analizując wpływ czynników jakościowych na wybór sklepu dyskontowego jako miejsca zakupu produktów mleczarskich, można stwierdzić, że najsilniejszy stymulujący wpływ na decyzje badanych konsumentów mają czynniki sensoryczne oraz zdrowotność produktów mleczarskich. Wpływ pozostałych zmiennych okazał się nieistotny.

\section{Literatura}

[1] Angowski M., Kijek T.: Segmentacja nabywców na podstawie analizy czynników wpływających na wybór produktów żywnościowych. HSS, 2017, 3 (22), 9-20.

[2] Balicki A.: Statystyczna analiza wielowymiarowa i jej zastosowania społeczno-ekonomiczne. Wyd. Uniwersytetu Gdańskiego, Gdańsk 2009.

[3] Barska A.: Atrybuty produktu żywnościowego a decyzje konsumentów. Handel Wewnętrzny, 2018, 3 (374), 37-47.

[4] Cyrek O., Grzybek M., Makarski S.: Kreowanie jakości handlowej artykułów żywnościowych. Wyd. Uniwersytetu Rzeszowskiego, Rzeszów 2016. 
[5] Domańska K., Angowski M.: Consumer attitudes towards products of regional manufacturers and their impact on the purchasing behavior on the market for dairy products. JARD, 2017, 4 (46), 739746.

[6] Góralczyk M.: Konsumenckie uwarunkowania przewag i konkurencyjności przedsiębiorstw przemysłu spożywczego. Rocz. Nauk. SERiA, 2010, 4 (12), 95-99.

[7] Grębowiec M.: Wpływ czynników warunkujących jakość na podejmowanie decyzji nabywczych na przykładzie produktów mięsnych. Rocz. Nauk. SERiA, 2015, 4 (17), 86-91.

[8] Greene W.H.: Econometric Analysis. Pearson Education, Upper Saddle River, New Jersey, 2005.

[9] Haas R., Canavari M., Imami D., Gjonbalaj M., Gjokaj E., Zvyagintsev D.: Attitudes and preferences of Kosovar consumer segments toward quality attributes of milk and dairy products. J. Int. Food Agribus. Marketing, 2016, 28 (4), 407-426.

[10] Kafel P., Nowicki P., Sikora T.: Produkty wysokiej jakości w polskich sieciach handlowych. Handel Wewnętrzny, 2013, 5 (346), 68-79.

[11] Kucharska B.: Sklepy dyskontowe w strukturze handlu detalicznego w Polsce. Perspektywa klienta. Handel Wewnętrzny, 2016, 3 (362), 195-205.

[12] Lipowski M., Angowski M.: Zachowania rynkowe nabywców produktów żywnościowych w sklepach dyskontowych. Handel Wewnętrzny, 2014, 2 (349), 125-137.

[13] Maciejewski G.: Miejsca zakupu żywności polskich konsumentów. Handel Wewnętrzny, 2018, 1 (372), 99-108.

[14] Mącik R., Nalewajek M.: Charakterystyki sposobu podejmowania decyzji zakupowych a wybór wirtualnego lub fizycznego kanału zakupu. W: Marketingowe sposoby kreowania wartości dla klienta. Red. M. Awdziej, G. Mazurek, P. de Pourbaix. Instytut Badań Rynku, Konsumpcji i Koniunktur, Warszawa 2013, ss. 228-236.

[15] Mazurkiewicz P.: Dyskonty coraz mocniejsze [on line]. Rzeczpospolita. Dostęp w Internecie [15.08.2019]: https://www.rp.pl/Handel/311019941-Dyskonty-coraz-mocniejsze.html

[16] Niewczas M.: Kryteria wyboru żywności. Żywność. Nauka. Technologia. Jakość, 2013, 6 (91), 204219.

[17] Nieżurawski L., Śmiatacz K., Kucharski A., Krajewski K.: Postrzeganie jakości produktów mleczarskich przez konsumentów. Zarządzanie i Finanse, 2012, 3 (3), 88-103.

[18] Sajdakowska M., Gębski J., Gutkowska K., Żakowska-Biemans S.: Importance of health aspects in Polish consumer choices of dairy products. Nutrients, 2018, 10 (8),\#1007, 1-12.

[19] Szczucki C.: Zakresy znaczeniowe podstawowych pojęć w kontroli produktów mięsnych. Gospodarka Mięsna, 1970, 1, 2-5.

[20] Szwacka J.: Kierunki zmian na rynku żywnościowym w Polsce, Zesz. Nauk. SGGW, EiOGŻ, 2007, 62, 81-95.

[21] Szwacka-Mokrzycka J.: Specyfika marketingu w agrobiznesie. Przegląd koncepcji. Handel Wewnętrzny, 2016, 5 (364), 305-313.

[22] Tul-Krzyszczuk A.: Wybrane uwarunkowania rozwoju sklepów dyskontowych i convenience w Polsce. Rocz. Nauk. SERiA, 2010, 4 (12), 341-345.

[23] Twardzik M., Bilińska-Reformat K.: Discount chains in the small towns and rural areas in Poland. Studia Regionalia. J. Pol. Acad. Sci., 2016, 46, 59-72.

[24] Urban S., Michałowska M.: Determinanty wyboru konsumentów dotyczące miejsca zakupu. Raport z badań. Nauki o Zarządzaniu, 2013, 3 (16), 133-153. 


\title{
EFFECT OF QUALITATIVE DETERMINANTS OF DAIRY PRODUCTS ON CHOOSING DISCOUNT STORES AS PLACE OF PURCHASING THEM BY YOUNG BUYERS
}

\author{
$\mathrm{S} u \mathrm{~mm}$ a r y
}

Changes in the commercial sector cause that the present-day market of food products is characterized by high volatility and unpredictability. An important element of creating a competitive strategy for entities operating on a given market is to know and understand the factors that shape buyers' choices of products and purchase places. In Poland the development of discount chains was reported. Until recently, for the most part, low prices in the discount stores encouraged Polish buyers to purchase in those stores, however over time the growing requirements of discount customers became a key factor in the development of new sales models in the discount stores. They started a process of changing the concepts of their standards through improving the offer of products with regard to the quality.

The objective of the paper was to assess the effect of some selected quality factors of food products on the buyer decisions related to selecting discount stores as a place of purchase. The research part was developed on the basis of surveys carried out in 2016 on a group of 358 buyers of dairy products using a targeted selection method. A CAWI method supported by a PAPI method was used to collect data. In the statistical analyses describing behaviours of the purchasers surveyed, a factor analysis was used and a probit model was applied to model consumer decisions on selecting the place of purchase (i.e. the discount store). The conducted research confirmed that the quality features were of crucial importance for the young buyers of dairy products while making their purchasing decisions. On the basis of the analysis of the effect of qualitative factors on the selection of the discount store as a place to purchase dairy products, it was found that sensory factors and the healthfulness of the products had the strongest stimulating effect on the consumer decisions.

Key words: discount stores, dairy products, behaviours of young buyers, quality 